\title{
THE WAR AND ABOLITION IN MISSOURI.
}

\section{BY SAMUEL PRENTIS OURTIS.}

Many years ago their lived in the city of St. Louis a youn lady of high social position and brilliant attractions. For the honor of claiming her hand in marriage there were tw aspirants - the one a rising young lawyer, of a distinguished family; the other a young lieutenant in the army. $\mathrm{Tl}$ lady's father was a celebrated statesman and a man of grea political influence. He favored the hopes of the young lawyer, but the lady's heart was given to the young lieuten ant. To obtain an alliance with the promising son of a prominent politician, and to remove from his danghter any counter-attractions, the father obtained, through his political influence with the government, what was substantially a

- decree of banishment, in the form of an order assigning the lieutenant to the duty of surveying the rapids in the Des Moines river, at Croton, Iowa. At this then remote point. it was hoped that the lieutenant would forget the lady, or a least that she would forget him, and yield to the wishes o his rival. But the lady proved herself possessed of as muc firmness and decision as her parent. She persistently refuse to marry any one save the man whom she loved, and in the end there was an elopement with the favored young officer, marriage by a Catholic priest, and a reconciliation of fathe daughter and son-in-law.

Y ears elapsed. The father continued to occupy a his political position, until finally he passed away. The lieuten tant became a distinguished officer of the army, an explorel tof unknown regions, the conqueror of California, and almos the President of the United States. The young lawyer alsi acquired fame and political standing as the advocate of a despised but glorious cause. He appeared in Congress as thi first and only "Free Soil" member from a slave State, anl his name was dear to every anti-slavery man in the nation,

The lady was Jessie, the daughter of Thomas H. Benton who declined an alliance with Frank P. Blair to marry Johr Charles Fremont. 
Such is a story which history may perhaps never be able demonstrate by anything resembling positive evidence. $t$ it is related by people who at the time, perhaps, knew as ch of the true nature of the affair as the public ever knows of in an elopement so conspicuous in history as was that of sie Benton and John C. Fremont. If the tale is true, its ation to events hereafter mentioned will be apparent.

To those who have studied closely the character of Frank Blair, the violence of his personal antipathies and the rerkable manner in which they pervert and distort his judgont of individuals, together with his jealousy of opponents, pst be evident. Thus during the war he suddenly appeared om the army in St. Louis, and in a public meeting denounced cretary Chase, and in the strongest of terms accused him of arpation of power and unlawful ambition. This sudden mity apparently arose from a seizure, by some of Chase's ents, of a large quantity of liquors shipped to Blair, with ) Int before Vicksburg; besides which Chase stood forard in the Cabinet of Lincoln as the advocate of emancipan, and in opposition to the policy of the Blairs. To the iter's personal knowledge, while commanding the. Departent of the Missouri, General Curtis made unusual exertions conciliate Blair and aid him in the work of raising a brig; yet Blair testified before a Congressional Committee Geheral Curtis threw unnecessary impediments in the y of ais success. Again, during the late Presidential camgn, Blair publicly accused Grant of designing the overot of the government and the establishment of a despotTo any one knowing the honest, unambitious, though rved, nature of Grant, this charge appears simply ridic18. Even if General Blair is sincere in making such gyes, it must be evident to a dispassionate mind that they the results of a judgment utterly blinded by personal bosity. A wise man would be more guarded in denunciaof a known traitor or demagogue, were it only from regard own reputation.

A April, 1861, the war of the rebellion burst upon the land. mont, in anticipation of events, had gone to Europe to 
purchase arms. On his return, it was said, he was to be mad commander of the western army. But, in the meantime Missouri was brought into a state of incipient rebellion by the artifices of a traitor Governor and his associates, and Camp Jackson sprang into existence, at St. Louis full of armed rebels. Suddenly Blair and Lyon organized the loyal Germans of St. Louis and surrounded and captured the camp The rebels concentrated under Price were defeated by Lyon and Sigel, and the greater part of the State fell into Union hands. The State Convention assembled, deposed the fugi tive Governor, and organized a Provisional Government, with Hamilton R. Gamble at its head. There were no longer any? political parties. In St. Louis and the larger towns the Unionte men held sway, and among them there was no interna division; while in nearly all unprotected localities the tebelf reigned supreme, either by force or by terror. During alson these early days of the war no man stood higher in popular ity or possessed more influence among Uuion men than ColriFrank P. Blair.

But the kaleidoscope of events changed. Fremont ap peared and assumed command of the "Western Department." The war was asuming a grander scale and his was the diffi cult task of organizing armies, governing a rebellious coun try, fortifying important points and laying the foundation od 1 a general system of operations. His course has been sever y. criticised. It is perhaps open to criticism in many respects It was said that with large numbers of troops he sacrifices Lyon and Mulligan, and let the rebels overrun the State, ancid he was also accused of tremendous extravagance.

History tells that on the whole he did about the best the was possible with the few troops really under his command while the charge of extravagance was possibly better sus $h$ tained. Faithful to his principles, he issued, rather prems. turely, a proclamation of emancipation to the slaves of rebel within his lines. This proclamation was annulled by Presi dent Lincoln on the ground that if such a proclamation shoul become expedient, it should be of general application and no be confined to one section of the rebellion. It marked, how 
er, not only in Missouri but throughout the north, the benning of the struggle between parties, which resulted in the rar being directed not merely to the preservation of the Inion, but to the total overthrow of slavery throughout the and.

But the most unlooked for and most powerful enemy of fremont had been found in Col. Frank 'P. Blair, member of Congress. Made to occupy a secondary figure on the stage ffevents and perhaps with a memory stored with the hatred rising from former rivalry for the handof Jessie Benton, he ould not patiently allow himself to be eclipsed by the splendor of Fremunt's name and prestige. He filled the ears of tis brother, Montgomery, in Lincoln's Cabinet, with tales of Fremont's extravagance, arrogance and inefliciency. He ras arrested by Fremont for communicating with the latter's eperiors out of the regular military channel, but was released the intercession of Lincoln.

Meanwhile the contest gained strenth and importance, and the whole land was scandalized by a quarrel between leaders * such a critical period. Blair found that his course had lost im the support of his best friends. The anti-slavery element and the Union, liberty-loving Germans turned coldly from bim and rallied around Fremont, whose emancipation scheme promised an end of the war. But the pro-slavery Union men, the old Democrats and the non-belligerent rebels gathered Found Blair and continued the struggle which he had inauprated. Thus this personal quarrel, claimed by some to wre had its commencement in a rivalry for the love of a bidy, was made the instrument for a revival of political urties in Missouri. It aroused old animosities, divided the hionists, and temporarily aided the cause of rebellion. At ength Fremont was removed. This was a step which caused tremendous public excitement throughout the land. A milthy insurrection on the part of Fremont and his friends was tren feared by the administration, which looked at events in lissouri through the spectacles of Montgomery Blair, and Rdward Bates, Attorney General, and steps were taken to revent an outbreak in St. Louis. But no insurrection oc- 
curred. Fremont retired, soured and embittered against the administration by the stigma of failure. Never again did he occupy as prominent a position during the war. The reputa tion of Blair as a Free Soil leader and his popularity among his old constituents in St. Louis was lost. Stung by the sneer of former friends, he gradually abandoned his political principles, and finally joined the so-called "Conservative" opposition. But not even a fine war record subsequently gained could ever restore him his lost political prominence. Witl his victory in the removal of Fremont he drops out of Missouri politics altogether, as a figure of any importance, and with that victory over the first emancipator of the war, slavery in Missouri commenced its descent to destruction.

Meanwhile the war went on. Fremont was succeeded by Hunter, who was almost immediately followed by Henry W. Halleck. Halleck was a man of fine education and great executive abilities, but possessed a harsh and irritable temper and a fault finding disposition. Almost his first step was to issue his famous General Order No. 3, which forbade the reception of fugitive slaves within our lines and directed their return to their masters. This filled the Conservative party with joy and drew upon Halleck for a time the wrath of the Radical Unionists. The opposition which the order excited marked the progress of anti-slavery sentiment. But having organized his armies under Grant, Pope and Curtis and pushed them into the field, he won such a brilliant series of Union victories at Forts Henry and Donaldson, Island Ten, Pea Ridge and Shiloh, as to silence for a time the voice of criticism. Thus during his administration in his "Depart ment of the Mississippi" he was enabled to keep out of the whirling vortex of Missouri politics.

But the conflict had nevertheless not ceased. When Halleck left St. Louis and went to Corinth, he left Schotieli in command of the State. As guerrilla outrages were fre quent, now that the main theater of operations had beer pushed south of the State, it was thought that Missouri should protect itself. A peculiar organization, the "Missouri State Militia," was organized, which, although mustered into the 
United States military service, was to be retained in Missouri under the Department Commander. Besides this, all ablebodied men were placed by Schofield in the "Enrolled Mispuri Militia." Of these those only who claimed to be loyal reve liable to be ordered on duty in emergencies, while those ho were enrolled as "rebel sympathizers" were exempted from military service, but under certain not very comfortable conditions. All political parties claimed to be loyal supporters of government. But while the various factions, such as "claybanks," or pro-slavery Unionists, old Democrats, and concealed rebels called themselves "the Conservative Union party," the unconditional anti-slavery Union men and admirers of Fremont were at first in contempt styled "radicals" and "charcoals." They accepted these titles openly and carried them to ultimate victory.

In September, 1862, General Samuel R. 'Curtis took command of a new Department including the State and styled the "Department of the Missouri." Very soon he began to find himself involved in political complications. Thoroughly loyal and anti-slavery, he could not ignore the most sincere, if not always the wisest Unionists ; while on the other hand he could not sympathize with or assist a party which, calling itself Conservative, was steadily in opposition to the whole current of events throughout the Union towards emancipation and Union, under any circumstances. At the head of the Conservative party now stood Governor Hamilton R. Gamble, and General Curtis found it impossible to be the head of the Union army, without willingly or unwillingly becoming the representative of the Radical party. These two men therefore took up the quarrel in which Blair and Fremont had become mutually exhausted. Soon the current of events ceased to flow smoothly between the Governor and the General. Gamble claimed control, to a great extent, of both State and Enrolled Militia. He refused to order the Enrolled Militia into service when Curtis called for them, and declined to make appointments which the latter deemed necessary, while the friendship exhibited by Curtis for the Radicals was biterly denounced. The emancipationists were accused of jeing Jacobins and Revolutionists. 
All efforts of the General to reconcile parties proved uniti availing. It was now evident that emancipation in Missour it was unavoidable, and the struggle was to lie between th ine Conservatives favoring gradual, and the Radicals favoring im it mediate, abolition. Whichever obtained control of the Statimal Legislature would prove victorious. Because he was sup posed to be using his influence to give political aid to th

Radicals, a war was waged upon Curtis similar to that which Fremont had encountered. Politicians intrigued against him Gamble blocked the wheels of public policy, and Attorney General Bates, with Halleck, now at the head of the army and others, demanded his removal of Lincoln. Curtis, dis gusted with his treatment, asked to be relieved. Finally Lincoln, protesting his desire to re-unite all Union men in Missouri under the one banner of Loyalty, removed Curtis, because, as he stated, he could not remove Gamble. This was a second victory for slavery in Missouri, and a victory which worked its utter ruin. The Radicals continually. gained power, but they looked coldly upon the President.

In May, 1863, General John M. Schofield succeeded Curtis. $\mathrm{He}$ was at heart as thoroughly anti-slavery and as firmly a lover of the Union as the most earnest Radical. But he was a good soldier, and this fact placed him in an entirely false position as the representative of a hated policy. Lincoln stated the causes which had led to the removal of Curtis, and instructed Schofield to stand aloof from all parties, but quarrel with none. If he was attacked equally on all sides he might feel assured that his course was correct.

Under these singular instructions Shofield endeavored to act. He at once found that the only way to avoid a quarrel with Gamble was to yield to his demands. The re-appointment of Col. Dick, a Radical, as Provost Marshal General, requested by Schofield, was refused, and the General was compelled to accept Broadhead, a Conservative of the Gamble school. At once the Radicals commenced war on Schofield, and during his entire term it was continued with unremitting vigor. The Conservatives succeeded in passing a scheme for gradual emancipation through the State Convention of 1861 , 
ill kept alive. Schofield, crippled by instructions and his eculiar situation, was compelled apparently to acquiesce in any Conservative movements, in the hope of preserving the ready lost unity of the Union party in Missouri. But as hey seemed to be deserted alike by the National and State iovernments, and by the General of the Department, the ladicals renewed the fight with a more desperate energy tan ever. They won the sympathy of the loyal North, and, sore to the purpose, they gained the political supremacy in he State. A new State Convention was called by a Radical egislature, and this Convention when elected proved Radical a strong majority.

Meanwhile Schofield, weary of a false position in opposiion to the Unionists of the State, weary of bearing an idle rord as the satellite of Governor Gamble, asked to be reered and sent into the field. His request was backed by a emand to the same effect from the triumphant Radicals. It ras granted, and he left Missouri unregretting and unreretted. But it was not long before the public began to see hat a soldier, whose faithful obedience to orders had brought dium upon his name, was made of far truer and better maerial than the excitement of political contests had ever preiously suffered to appear.

In December, 1863, he was followed in command by losecrans, and the administration was virtually compelled to cknowledge its blunder by restoring Curtis to most of his old urritorial command (all save the State of Missouri) on Janary 1st, 1864. Providentially, as it seemed to prevent conict and restore peace, Gamble died about the time Rosecrans mived in St. Louis. The Radicals held the State, and all arties had wearied of continual warfare on the Department ommander. Moreover he had no power, even if he had ossessed the will, to check the progress of Radical triumph. lence he was suffered to hold his command in peace, a comand of little importance save during the brief though enerthe invasion of Price in the fall of 1864 .

The State Convention assembled, abolished slavery, and 
established the present Constitution of the State, with all it perhaps too severe features towards rebels and rebel sym pathizers. This was their victory of principle. Their vic tory as a party occurred at the National Republican Conven tion at Baltimore. The Conservative delegation, instractec to vote for the re-nomination of Lincoln, the first choice $a_{\text {julf }}$ every other State, was rejected in favor of the Radical delega tion, which alone cast its vote against Lincoln and for Gran on the first ballot.

Since the abolition of slavery the path of Missouri has beer onward and upward towards prosperity, and, if the tale with which this article is commenced be true, who can estimate the indirect influence which has been exerted over the fate of a great State by so simple a thing aș a woman's choice of a husband.

\section{EDITORIAL REMARKS.}

The present number closes the volume of 1869 , and closes also a threetr: years editorship of the ANNALs of the present incumbent. In view of s many considerations involved in our future relation to it, we have good: reason for regarding it also as the end of our editorial management of it $t$ As it 18, our occupancy of its historical tripod has continued nearly doublewt the time of any one of our three predecessors; and the historical mattejut published in its pages exceeds by over four hundred pages the amounrite contributed and procured by all who have preceded us in this field eils labor. Therefore, with a profound consciousness of the many imperfetns tions and shortcomings of our work, we have fewer misgivings than as it had been in its results less abundant.

We review with pleasurable sensations now, the solicitude of our earl experience with its duties, and the persistent, almost painful, solicitation. we made with those who hold the keys to the kind of knowledge desireo by which its pages have been filled; and we have this self-gratification that if we have not been able to strike satisfactorily every vein of Stati. History, it is because of obstacles insurmountable with the means at ou command, and of a character to be fully appreciated only when tried Prominently are these: it is only comparatively few of the men who carr in therr memories the facts of the early years of the State, who can be er it ticed into the uncompensated trouble of a written record of their remer brances. Many who are the only remaining participators in importantoe transactions find insurmountable difficulties in the way of a preparation o articles for publication, and co-operative aid is only rarely at hand to secur mo them. 
Copyright of Annals of Iowa is the property of State of Iowa, by \& through the State Historical Society of Iowa and its content may not be copied or emailed to multiple sites or posted to a listserv without the copyright holder's express written permission. However, users may print, download, or email articles for individual use. 